\title{
Novel highly-soluble peptide-chitosan polymers: Chemical synthesis and spectral characterization
}

\author{
M.K.S. Batista ${ }^{a, b}$, L.F. Pinto ${ }^{a, b}$, C.A.R. Gomes ${ }^{a}$, P. Gomes ${ }^{b, *}$ \\ ${ }^{a}$ Laquipai, Departamento de Química, Faculdade de Ciências da Universidade do Porto, Rua do Campo Alegre 687, P-4169-007 Porto, Portugal \\ ${ }^{\mathrm{b}}$ CIQUP, Departamento de Química, Faculdade de Ciências da Universidade do Porto, Rua do Campo Alegre 687, P-4169-007 Porto, Portugal
}

Received 31 October 2005; received in revised form 25 November 2005; accepted 30 November 2005

Available online 18 January 2006

\begin{abstract}
Novel water-soluble polymers, $N$ - $(\gamma$-propanoyl-valin)-chitosan and $N$ - $(\gamma$-propanoyl-aspartic acid)-chitosan, were synthesized by reaction of low molecular weight chitosan with $N^{\alpha}$-(3-bromopropanoyl)-valine and $N^{\alpha}$-(3-bromopropanoyl)-aspartic acid, respectively, under mild conditions. Prior to reaction with chitosan, the peptide substituents have been prepared by standard peptide chemistry methods from 3 bromopropanoic acid and the relevant $\alpha$-amino acid tert-butyl esters. The chemical structure and physical properties of the novel chitosan derivatives were characterized by ${ }^{1} \mathrm{H}$ NMR and IR spectroscopy. The polymers are highly soluble in a wide $\mathrm{pH}$ range, which opens new perspectives for the applications of chitosan-based materials.
\end{abstract}

(C) 2005 Elsevier Ltd. All rights reserved.

Keywords: Chitosan; $N$-( $\gamma$-propanoyl-valin)-chitosan; $N$-( $\gamma$-propanoyl-aspartic acid)-chitosan; Peptide; Polymer

\section{Introduction}

Chitosan, a $\beta$-(1 $\rightarrow 4)$-2-amino-2-deoxy- $\beta$-D-glucopyranose, is a hydrophilic, biocompatible and biodegradable polysaccharide prepared by $\mathrm{N}$-deacetylation of chitin, which is the main structural component of crab and shrimp shells. The chitosan has many distinctive properties such as antimicrobial activity, non-toxicity and remarkable affinity to proteins.

Chitosan and its derivatives have been receiving increasing attention in diverse areas such as food science, water purification, the pulp and paper industry, pharmacy or medicine (Felse and Panda, 1999; Bernkop-Schnürch, Humenberger, \& Valenta, 1998; Britto \& Campana-Filho, 2004; Hu, Jiang, Xu, Wang, \& Zhu, 2005; Mathur \& Narang, 1990; ParraBarraza et al., 2005; Santos, Dockal, \& Cavalheiro, 2005; Varna, Deshpande, \& Kennedy, 2004). The presence of $\mathrm{OH}$ and $\mathrm{NH}_{2}$ groups in chitosan improves hydrogen bonding assisted with sufficient flexibility of the linear chain, whose conformation is highly dependent on ionic strength, and confers mucoadhesive properties to the biopolymer $(\mathrm{He}$,

\footnotetext{
* Corresponding author. Tel.: +351 226082863; fax: +351 226082959.

E-mail address: pgomes@fc.up.pt (P. Gomes).
}

0144-8617/\$ - see front matter (C) 2005 Elsevier Ltd. All rights reserved. doi:10.1016/j.carbpol.2005.11.040
Daves, \& Illum, 1998; Smart, Kellaway, \& Worthington, 1984). Furthermore, the cationic polyelectrolyte nature of chitosan can provide a strong electrostatic interaction with mucus or negatively charged mucosal surfaces, reinforcing the important mucoadhesive properties that have been demonstrated for chitosan-based materials (Bernkop-Schnürch \& Apprich, 1997; Bernkop-Schnürch \& Krajicek, 1998; BernkopSchnürch \& Kast, 2001).

However, practical applications of chitosan are limited by its insolubility in water at $\mathrm{pH}$ higher than 6 . Various chitosan derivatives have been designed to overcome this obstacle (Muzzarelli, Tanfani, Emmanuelli, \& Mariotti, 1982; Muzzarelli, Weckx, Filippini, \& Lough, 1989). One of the most popular ways to provide a hydrophilic character to this polysaccharide is through carboxylation. $\mathrm{N}$-(2-carboxyethyl)chitosans have been prepared in our group (Skorik et al., 2003) and their metal complexation properties (Skorik et al., 2005) and potential applications as antioxidant and antimutagenic agents (Kogan et al., 2004) have been studied. We now aim the development of novel water-soluble chitosan-based materials, with potential environmental or biomedical applications, such as extraction of heavy-metal pollutants or controlled drug release in vivo, respectively.

We herein report the synthesis of two novel chitosan-based polymers, $N$ - $(\gamma$-propanoyl-valin)-chitosan and $N$ - $(\gamma$-propanoyl-aspartic acid)-chitosan, prepared from low molecular weight chitosan and $N^{\alpha}$-(3-bromopropanoyl)-valine 
or $N^{\alpha}$-(3-bromopropanoyl)-aspartic acid, by a previously reported method (Skorik et al., 2003).

The $N^{\alpha}$-(3-bromopropanoyl)-valine and $N^{\alpha}$-(3-bromopropanoyl)-aspartic acid substituents were prepared from 3-bromopropanoic acid and the tert-butyl esters of L-valine and L-aspartic acid, respectively, through standard peptide coupling chemistry. The final polymer products were characterized by ${ }^{1} \mathrm{H}$ NMR and IR spectroscopy.

\section{Experimental}

\subsection{Materials}

Low molecular weight chitosan from coarse ground crab (ref. 44.886-9, degree of acetylation 0.10 , as determined by ${ }^{1} \mathrm{H}$ NMR), 3-bromopropanoic acid, $N, N^{\prime}$-dicyclohexylcarbodiimide (DCCI), $\mathrm{CDCl}_{3}, \mathrm{D}_{2} \mathrm{O}, \mathrm{DCl}$, anhydrous trifluoroacetic acid (TFA) and common organic solvents (p.a. quality) were all from SigmaAldrich. L-valine tert-butyl ester hydrochloride and L-aspartic acid $\beta$-tert-butyl $\alpha$-tert-butyl ester hydrochloride were both from Bachem (Switzerland). Thin layer chromatography (TLC) plates (aluminum foil covered with $0.25 \mathrm{~mm}$ thick silica gel 60 , $\mathrm{F}_{254}$ ) were from Merck (VWR International), and silica gel for column chromatography (Chromagel, $\mathrm{pH} 7,35-70 \mu \mathrm{m}$, $550 \mathrm{~m}^{2} / \mathrm{g}$ ) was from SDS (France). Dialysis membranes (MW cut-off $1 \mathrm{kDa}$ ) were from Spectra-Por (No. 132638).

\subsection{Synthesis}

\subsubsection{Peptide ligands}

$N^{\alpha}$-(3-bromopropanoyl)-valine and $N^{\alpha}$-(3-bromopropanoyl)-aspartic acid were prepared (Scheme 1) as will be reported in detail elsewhere (Pinto, Batista, Skorik, Gomes \& Gomes, in preparation). Briefly, the relevant L-amino acid tertbutyl esters were obtained as free amines (amino acid $\boldsymbol{\alpha}$-amino group) after neutralization of the corresponding hydrochlorides with $\mathrm{NaOH}(30 \%)$, followed by extraction with dichloromethane. These L-amino acid tert-butyl esters were then reacted with 3-bromopropanoic acid in the presence of dicyclohexylcarbodiimide (DCCI) as coupling reagent. The reactions were monitored by TLC and the target $N^{\alpha}$-(3bromopropanoyl) amino acid tert-butyl esters were successfully isolated. Thus, pure esters were obtained after elimination of the urea (dicyclohexylurea, DCU) by-product that was precipitated with acetone at $4{ }^{\circ} \mathrm{C}$ (three cycles of overnight precipitation plus removal by suction filtration), followed by column chromatography on silica to remove unreacted amino acid tert-butyl ester. The structures of the tert-butyl esters were confirmed by ${ }^{1} \mathrm{H}$ and ${ }^{13} \mathrm{C} \mathrm{NMR}$. The esters were then cleaved by acidolysis with neat TFA, with quantitative formation of the corresponding free carboxylic acids, whose structures were also confirmed by NMR.

\subsubsection{Chitosan derivatives}

Chitosan $\left(0.2 \mathrm{~g}, 4.2 \mathrm{mmol}\right.$ of $\left.-\mathrm{NH}_{2}\right)$ was dissolved in water (60 mL) containing four equivalents of $N^{\alpha}$-(3-bromopropanoyl)-valine or $N^{\alpha}$-(3-bromopropanoyl)-aspartic acid (Scheme 2). A prescribed amount of $\mathrm{NaHCO}_{3}$ was then added and the reactions were allowed to proceed at $60{ }^{\circ} \mathrm{C}$ under magnetic stirring. Daily additions of $\mathrm{NaHCO}_{3}$ were done to keep $\mathrm{pH}$ within the 7-8 and 6-7 ranges, respectively. The products were purified by dialysis against deionised water for 5-7 days, and then freeze-dried on a Christ alpha 1-4 lyophiliser.

\subsection{Structural analysis}

NMR spectra were recorded on a Bruker AMX 300 spectrometer. Peptide ligands and their ester precursors were dissolved in $\mathrm{CDCl}_{3}$ with tetramethylsilane (TMS) as internal reference. Chitosan was dissolved in $1 \%(\mathrm{v} / \mathrm{v}) \mathrm{DCl} / \mathrm{D}_{2} \mathrm{O}$ and peptide-chitosan derivatives in $20 \%(\mathrm{v} / \mathrm{v}) \mathrm{DCl} / \mathrm{D}_{2} \mathrm{O}$ both with 3-(trimethylsilyl)-1-propanesulfonic acid as an internal standard for ${ }^{1} \mathrm{H}$ NMR chemical shifts. IR spectra were recorded on a Fourier-Transform Infrared (FTIR) spectrometer (Jasco FT/IR-460 instrument). KBr pellets of chitosan and peptidechitosan derivatives were used in the IR measurements. FTIR spectra were acquired after 32 scans between 4000 and $400 \mathrm{~cm}^{-1}$, with spectral resolution of $4 \mathrm{~cm}^{-1}$.

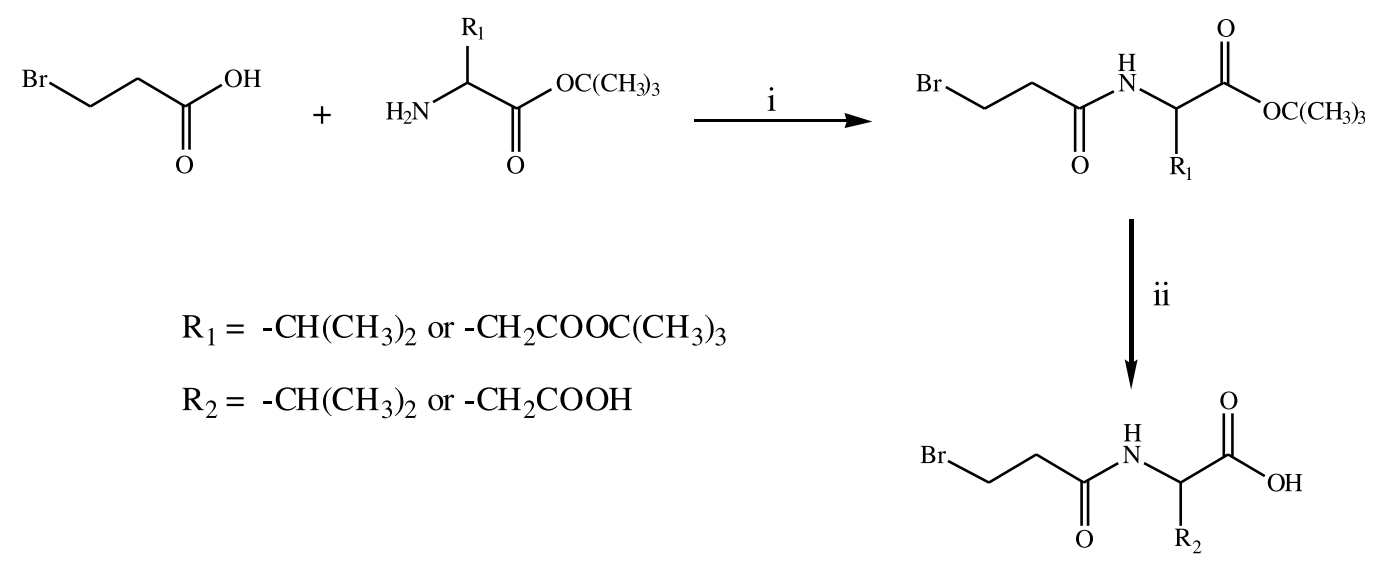

Scheme 1. (i) DCCI, dichloromethane; (ii) TFA, ethyl ether. 

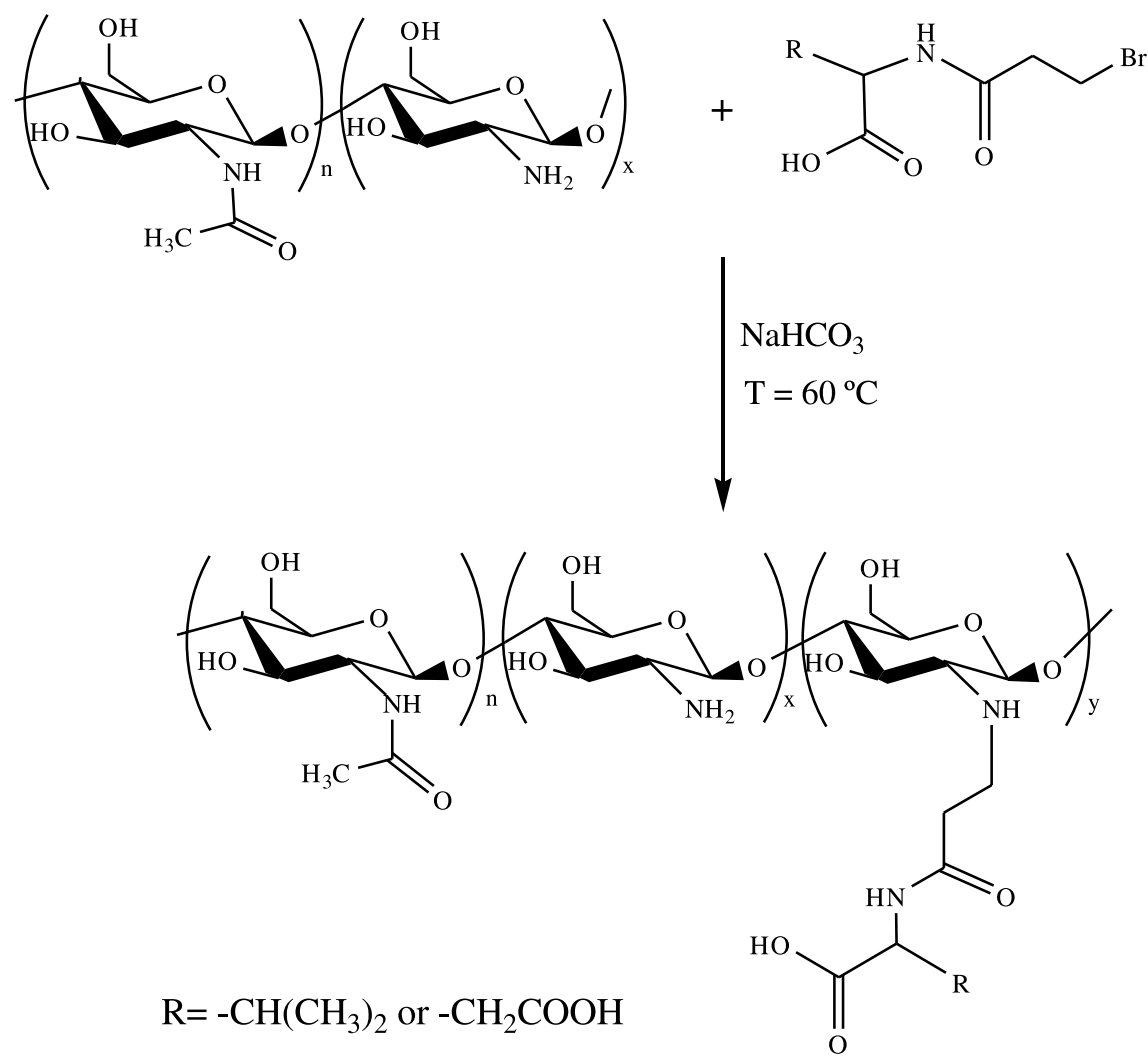

Scheme 2.

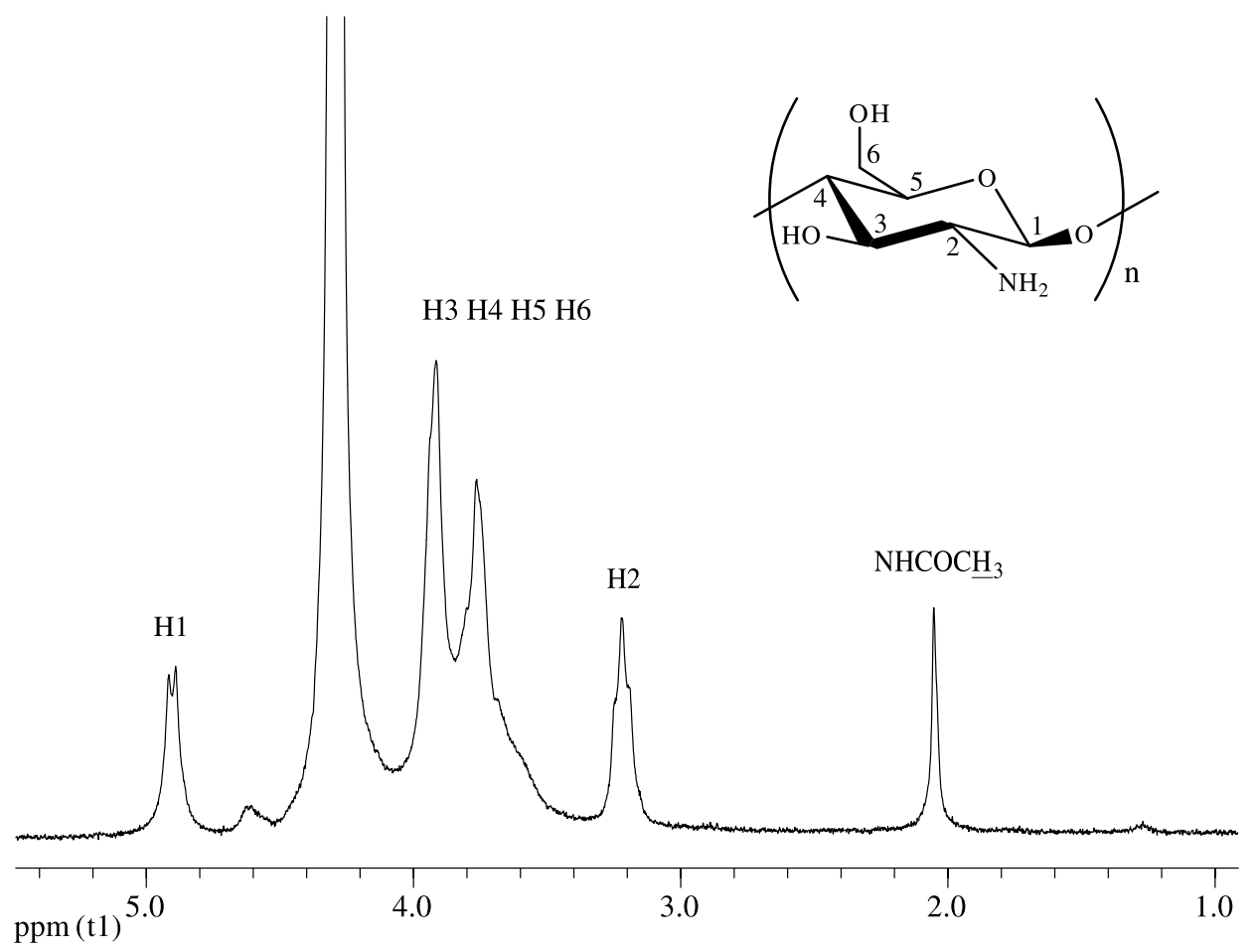

Fig. 1. ${ }^{1} \mathrm{H}$ NMR spectrum of chitosan in $\mathrm{D}_{2} \mathrm{O} / \mathrm{DCl}$ at $343 \mathrm{~K}$. 


\section{Results and discussion}

The syntheses of peptide ligands and peptide-chitosan derivatives were carried out as shown in Schemes 1 and 2, and the chemical structures were determined by ${ }^{1} \mathrm{H}$ NMR spectroscopy.
The ${ }^{1} \mathrm{H}$ NMR spectrum of $N$-( $\gamma$-propanoyl-valin)-chitosan (Fig. 2A) shows signals at 5.02 and $5.19 \mathrm{ppm}$ that were assigned to the H-1 hydrogen from monosubstituted and disubstituted units of D-glucosamine, respectively, and at $4.89 \mathrm{ppm}$, related to the $\mathrm{H}-1$ from unsubstituted D-glucosamine unit, characteristic of chitosan (Fig. 1). The spectrum of $\mathrm{N}-(\gamma-$
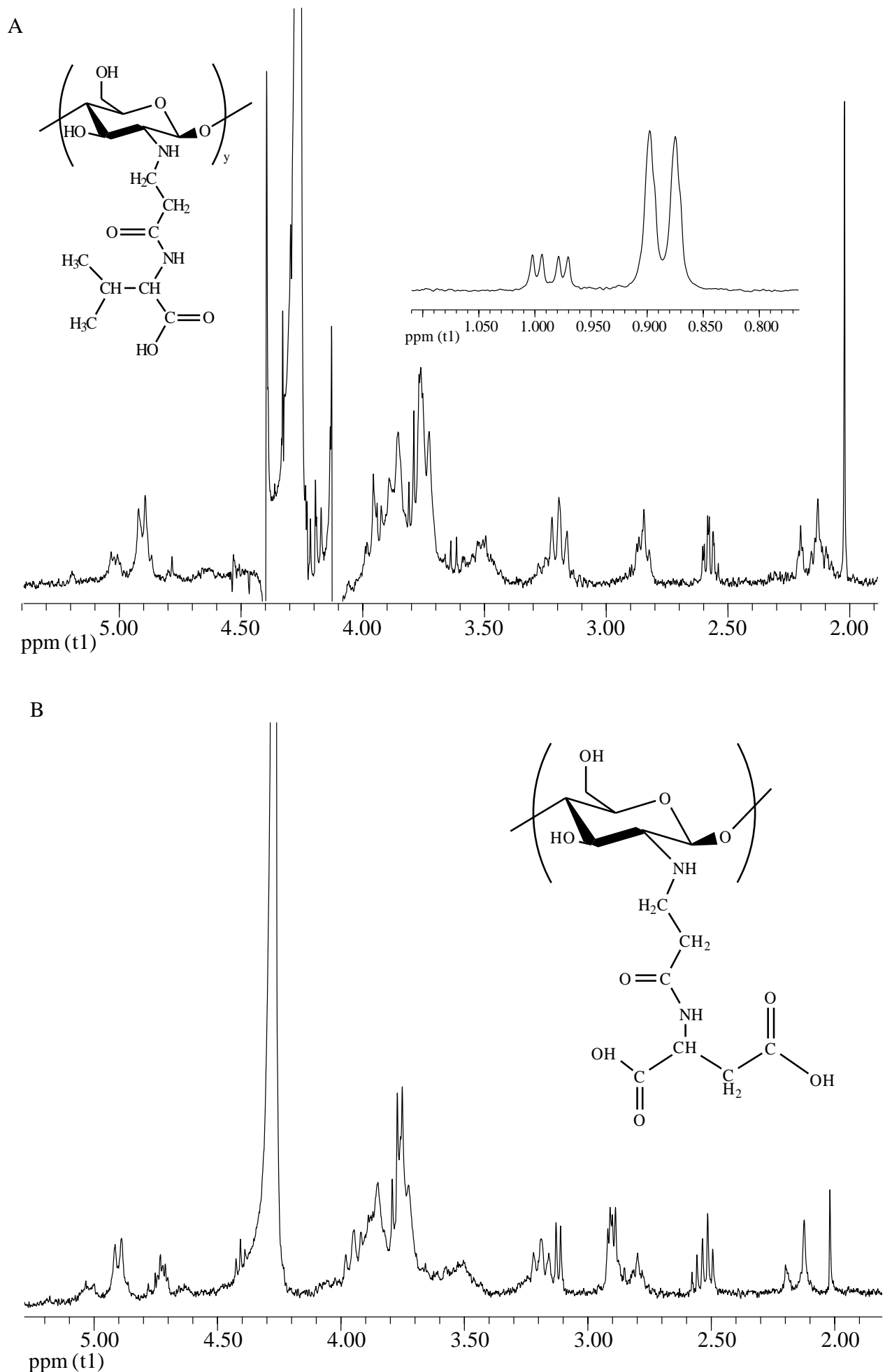

Fig. 2. ${ }^{1} \mathrm{H}$ NMR spectra (2-5 ppm) of (A) $N$-( $\gamma$-propanoyl-valin)-chitosan (the insert displays the $\sim 1$ ppm region) and (B) $N$-( $\gamma$-propanoyl-aspartic acid)-chitosan, in $\mathrm{D}_{2} \mathrm{O} / \mathrm{DCl}$ at $343 \mathrm{~K}$. 
Table 1

IR bands of chitosan and peptide-chitosan derivatives

\begin{tabular}{|c|c|c|c|}
\hline \multirow[t]{2}{*}{ Sample } & \multicolumn{3}{|l|}{ Infrared $\left(\mathrm{cm}^{-1}\right)$} \\
\hline & $\begin{array}{l}v_{\mathrm{C}=\mathrm{O}}(\text { stretching } \mathrm{C}=\mathrm{O} \text { of } \\
\text { substituent groups })\end{array}$ & $v_{\mathrm{C}=\mathrm{O}}($ amide $\mathrm{I})$ & $\delta_{\mathrm{NH}}($ amide II $)$ \\
\hline Chitosan & - & 1649.7 & 1564.9 \\
\hline$N$-( $\gamma$-propanoyl-valin)-chitosan & 1739.5 & 1644.9 & 1565.9 \\
\hline$N$-( $\gamma$-propanoyl-aspartic acid)-chitosan & 1724.0 & 1641.1 & 1565.9 \\
\hline
\end{tabular}

u, stretching; $\delta$, axial deformation.

propanoyl-aspartic acid)-chitosan (Fig. 2B) shows signals at 5.04 and $4.92 \mathrm{ppm}$ that were assigned to the $\mathrm{H}-1$ hydrogen from monosubstituted and unsubstituted D-glucosamine units, respectively.

The polymer degrees of acetylation (DA) and substitution (DS) have been determined from peak integrals. Thus, DA was calculated from the integrals of the $\mathrm{CH}_{3}$ peak of GlcNHAc units and corresponded to 0.10 for both chitosan derivatives. The DS was calculated in a similar way, using the integrals of the H-1 peaks from GlcNHR and GlcNR 2 units. For $N$-( $\gamma$-propanoyl-valin)-chitosan, a DS value of 0.32 was found, whereas for $N$ - $(\gamma$-propanoyl-aspartic acid)-chitosan, calculated DS was of 0.27 .

$N$-( $\gamma$-propanoyl-valin)-chitosan (Fig. 2A). $\delta_{\mathrm{H}} / \mathrm{ppm}\left(\mathrm{D}_{2} \mathrm{O} /\right.$ $\mathrm{DCl}, 300 \mathrm{MHz}): 0.89\left(1.40 \mathrm{H},-\mathrm{CH}\left(\mathrm{CH}_{3}\right)_{2}\right.$ of $\left.\mathrm{GlcNHR}\right), 0.98$ $\left(0.40 \mathrm{H},-\mathrm{CH}\left(\mathrm{CH}_{3}\right)_{2}\right.$ of $\left.\mathrm{GlcNHR}_{2}\right), 2.02\left(0.30 \mathrm{H},-\mathrm{NHCOCH}_{3}\right.$ of GlcNHAc), $2.58\left(0.32 \mathrm{H},-\mathrm{CH}\left(\mathrm{CH}_{3}\right)_{2}\right.$ of $\mathrm{GlcNHR}$ and $\left.\mathrm{GlcNR}_{2}\right), 2.85\left(0.50 \mathrm{H},-\mathrm{CH}_{2} \mathrm{CH}_{2} \mathrm{CON}-\right.$ of GlcNHR$), 3.22$ $\left(0.82 \mathrm{H}, \mathrm{H}-2\right.$ of $\mathrm{GlcNH}_{2}, \mathrm{GlcNHR}$ and $\left.\mathrm{GlcNR}_{2}\right), 3.95-4.00$ $\left(-\mathrm{CH}_{2} \mathrm{CH}_{2} \mathrm{CON}-\right.$ of GlcNHR and GlcNHR 2 , and $-\mathrm{H}-3,4,5,6$ of $\mathrm{GlcNH}_{2}, \mathrm{GlcNHR}_{\mathrm{C}}$ GlcNHR 2 and GlcNHAc), $4.65(0.10 \mathrm{H}, \mathrm{H}-2$ of GlcNHAc), $4.78(0.11 \mathrm{H}, \mathrm{H}-1$ of GlcNHAc $), 4.91(0.72 \mathrm{H}$, $H-1$ of $\left.\mathrm{GlcNH}_{2}\right), 5.02(0.24 \mathrm{H}, H-1$ of GlcNHR), $5.19(0.04 \mathrm{H}$, $H-1$ of $\left.\mathrm{GlCNHR}_{2}\right)$.

$N$-( $\gamma$-propanoyl-aspartic acid)-chitosan (Fig. 2B). $\delta_{\mathrm{H}} / \mathrm{ppm}$ $\left(\mathrm{D}_{2} \mathrm{O} / \mathrm{DCl}, \quad 300 \mathrm{MHz}\right): 2.08\left(0.30 \mathrm{H},-\mathrm{NHCOCH}_{3}\right.$ of GlcNHAc), $2.82\left(0.53 \mathrm{H},-\mathrm{CH}_{2}-\mathrm{CH}_{2} \mathrm{CON}-\right.$ of GlcNHR), 2.93 $\left(0.53 \mathrm{H}-\mathrm{CHCH}_{2} \mathrm{COOH}\right.$ of GlcNHR), $3.21(0.90 \mathrm{H}, \mathrm{H}-2$ of $\mathrm{GlcNH}_{2}$, GlcNHR), 3.40-4.10 (- $\mathrm{CH}_{2}-\mathrm{CH}_{2} \mathrm{CON}-$ of GlcNHR, $H-2$ of GlcNHAc and $-H-3,4,5,6$ of $\mathrm{GlcNH}_{2}$, GlcNHR, and GlcNHAc), $4.62(0.10 \mathrm{H}, H-1$ of GlcNHAc $), 4.76(0.26 \mathrm{H}$, $-\mathrm{CH}_{2} \mathrm{CHCOOH}$ of GlcNHR), $4.92\left(0.73 \mathrm{H}, \mathrm{H}-1\right.$ of $\left.\mathrm{GlcNH}_{2}\right)$, $5.04(0.27 \mathrm{H}, H-1$ of GlcNHR).

Table 1 shows the most important IR bands for chitosan and both peptide-chitosan derivatives. Thus, the spectrum of chitosan (Fig. 3) presents the following bands: axial stretching of the $\mathrm{OH}$ group at $3273.9 \mathrm{~cm}^{-1}$, amide I band (GlcNHAc units) at $1649.7 \mathrm{~cm}^{-1}, \mathrm{~N}-\mathrm{H}$ angular deformation at $1564.9 \mathrm{~cm}^{-1}$ (GlcNHAc amide II), $\mathrm{CH}_{3}$ symmetrical angular deformation at $1385.6 \mathrm{~cm}^{-1}, \mathrm{C}-\mathrm{N}$ axial deformation of the amino groups at $1411.6 \mathrm{~cm}^{-1}$ and $\mathrm{C}-\mathrm{N}$ axial deformation of the amino groups at $1324.8 \mathrm{~cm}^{-1}$, besides the three characteristic polysaccharide bands at 1152.3, 1096.3 and $1030.8 \mathrm{~cm}^{-1}$ (Santos et al., 2005).

Structural changes due to chitosan derivatization with the peptide ligands were confirmed by FTIR (Fig. 4). In comparison to the chitosan IR spectrum, the $N$ - $(\gamma$-propanoylvalin)-chitosan (Fig. 4A) and the $N$-( $\gamma$-propanoyl-aspartic acid)-chitosan (Fig. 4B) spectra display a new absorption peak at 1739.5 and $1724.5 \mathrm{~cm}^{-1}$, respectively, corresponding to the $\mathrm{C}=\mathrm{O}$ stretching mode of the carboxyl-functionalised substituents. The interpretation of the amide $\mathrm{I}$ (amide $\mathrm{C}=\mathrm{O}$ stretching) and amide II (amide $\mathrm{N}-\mathrm{H}$ bending) region is not trivial for the peptide-chitosan derivatives, as two different amide bonds, one from the original GlcNHAc $\left(-\mathrm{NHCOCH}_{3}\right)$ units and the other from the peptide ligand amide $\left(-\left(\mathrm{CH}_{2}\right)_{2}\right.$ $\mathrm{CONHCH}(\mathrm{R}) \mathrm{COOH})$, contribute to bands in this region. This leads to significant overlap that may be further aggravated by the presence of ionized groups giving rise to bands in the 1550$1650 \mathrm{~cm}^{-1}$ region $\left(-\mathrm{COO}^{-}\right.$stretching and $-\mathrm{NH}_{3}^{+}$deformation) (Lin et al., 2005) and by the $\mathrm{N}-\mathrm{H}$ bending vibrational modes of polymer primary $\left(-\mathrm{NH}_{2}\right)$ and secondary, i.e. monosubstituted (-NHR) amino groups. Nonetheless, interesting information can be withdrawn from the amide I band region of the IR spectra of chitosan derivatives. As mentioned above, NMR analysis of both derivatives has shown that polymer DS triples the value of its DA. Therefore, one should expect the peptide amide to be the major responsible for the characteristics of the IR amide I region of peptide-chitosan derivatives. In fact, a marked increase in absorption intensity at $\sim 1645 \mathrm{~cm}^{-1}$ is observed for both derivatives, relative to chitosan. One should not expect an increase of similar magnitude for the amide II absorption, as amide I is usually stronger than the corresponding amide II. Additionally, the increase in amide I intensity is accompanied by a bathochromic

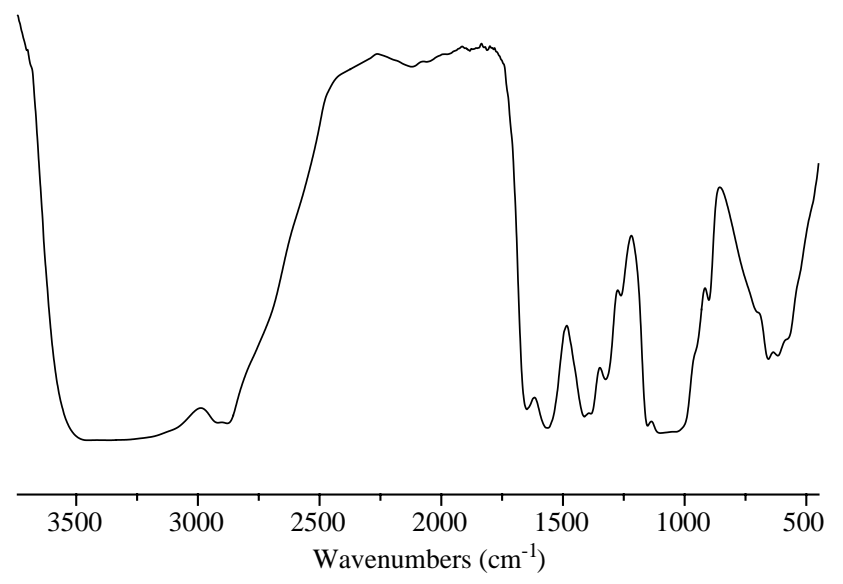

Fig. 3. IR spectrum of chitosan ( $\mathrm{KBr}$ pellets). 


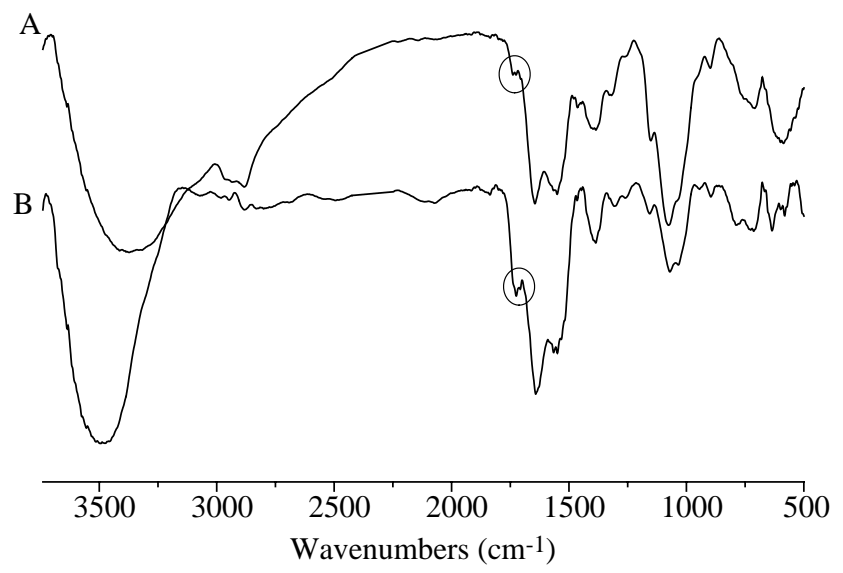

Fig. 4. IR spectra of (A) $N$-( $\gamma$-propanoyl-valin)-chitosan and (B) $N$ - $(\gamma$ propanoyl-aspartic acid)-chitosan ( $\mathrm{KBr}$ pellets).

shift of maximal absorbance $\left(\Delta \sim-5\right.$ to $-9 \mathrm{~cm}^{-1}$ ) relative to the parent polymer (Table 1). This shift can be ascribed to a lower frequency of the peptide amide $\mathrm{I}$ in comparison to GlcNHAc amide I. Such difference may be due to an intramolecular hydrogen bond between the amide oxygen and the terminal carboxyl group of the peptide ligand. This may explain the reason why the higher bathochromic shift $\left(\Delta \sim-9 \mathrm{~cm}^{-1}\right)$ is observed for the aspartic acid ligand, where two carboxyl groups are available for hydrogen bonding.

A major limitation for practical applications of chitosan arises from its insolubility in aqueous media at $\mathrm{pH}$ higher than 6 . We had the opportunity to test the aqueous solubility of $N$-( $\gamma$-propanoyl-valin)-chitosan and $N$ - $(\gamma$-propanoyl-aspartic acid)-chitosan in the $2-10 \mathrm{pH}$ interval, in the course of acidbase titration experiments (to be reported elsewhere). No polymer precipitation was observed in the entire $\mathrm{pH}$ range covered. In contrast, extensive precipitation of chitosan occurs at $\mathrm{pH} \geq 7$ in a similar experiment. These observations confirm that both peptide-chitosan derivatives herein reported are water-soluble in a very wide $\mathrm{pH}$ interval, in harmony with similar chitosan derivatives (Skorik et al., 2005). Further, given that solubility was increased due to insertion of peptide ligands at a relatively low DS $(\sim 0.30)$, these novel polymers are obviously soluble at $\mathrm{pH}$ lower than 2 and most probably also at $\mathrm{pH}$ higher 10. Thus, the novel chitosan derivatives herein reported are highly soluble at virtually any $\mathrm{pH}$ value, which opens new perspectives for the employment of chitosan-based materials in controlled drug-delivery and other biomedical or environmental applications.

\section{Conclusions}

$N$-( $\gamma$-propanoyl-valin)-chitosan and $N$ - $(\gamma$-propanoyl-aspartic acid)-chitosan were prepared by reaction of chitosan with peptide ligands in mild alkaline conditions and were characterized by ${ }^{1} \mathrm{H}$ NMR and IR spectroscopy. The insertion of the peptide ligands was confirmed by both spectroscopies, and ${ }^{1} \mathrm{H}$ NMR allowed us to determine the polymer degrees of acetylation (ca. 0.10) and substitution $(0.32$ for $N-(\gamma-$ propanoyl-valin)-chitosan and 0.27 for $N$ - $(\gamma$-propanoyl-aspartic acid)-chitosan).

The introduction of carboxyl-functionalized substituents in the polymeric structure of chitosan yielded novel polymers that are soluble in a very wide $\mathrm{pH}$ range, which undoubtedly widens the scope of application of chitosan-based materials.

\section{Acknowledgements}

The authors thank FCT for financial support to LAQUIPAI (CG) and to CIQUP (PG), and also for $\mathrm{PhD}$ grant SFRH/BD/13144/2003 (MB).

\section{References}

Bernkop-Schnürch, A., \& Apprich, I. (1997). Synthesis and evaluation of a modified mucoadhesive polymer protecting from $\alpha$-chymotrypsinic degradation. International Journal of Pharmaceutics, 146, 247-254.

Bernkop-Schnürch, A., Humenberger, C., \& Valenta, C. (1998). Basic studies on bioadhesive delivery systems for peptide and protein drugs. International Journal of Pharmaceutics, 165, 217-225.

Bernkop-Schnürch, A., \& Kast, C. E. (2001). Chemically modified chitosans as enzyme inhibitors. Advanced Drug Delivery Reviews, 52, 127-137.

Bernkop-Schnürch, A., \& Krajicek, M. E. (1998). Mucoadhesive polymers for peroral peptide delivery: Synthesis and evaluation of chitosan-EDTA conjugates. Journal of Controlled Release, 50, 215-223.

Brito, D., \& Campana-Filho, S. P. (2004). A kinetic study on the thermal degradation of $\mathrm{N}, \mathrm{N}, \mathrm{N}$-trimethylchitosan. Polymer Degradation and Stability, 8, 353-361.

Felse, P. A., \& Panda, T. (1999). Studies on applications of chitin and its derivatives. Bioprocess and Biosystems Engineering, 20, 505-512.

He, P., Daves, S. S., \& Illum, S. (1998). In vitro evaluation of the mucoadhesive properties of chitosan microspheres. International Journal of Pharmaceutics, 166, 75-88.

Hu, Y., Jiang, H., Xu, C., Wang, Y., \& Zhu, K. (2005). Preparation and characterization of poly(ethylene glycol)-g-chitosan with water and organosolubility. Carbohydrate Polymers, 61, 472-479.

Kogan, G., Skorik, Y. A., Žitňanova, I., Križková, L., Ďuračková, Z., Gomes, C. A. R., et al. (2004). Antioxidant and antimutagenic activity of N-(2-carboxyethyl)chitosan. Toxicology and Applied Pharmacology, 201, 303-310.

Lin, Y.-H., Chung, C.-K., Chen, C.-T., Liang, H.-F., Chen, S.-C., \& Sung, H.-W. (2005). Preparation of nanoparticles composed of chitosan/poly$g$-glutamic acid and evaluation of their permeability through Caco- 2 cells. Biomacromolecules, 6, 1104-1112.

Mathur, N. K., \& Narang, C. K. (1990). Chitin and chitosan, versatile marine animal polysaccharides. Journal of Chemical Education, 67, 938-942.

Muzzarelli, R. A. A., Tanfani, F., Emmanuelli, M., \& Mariotti, S. (1982). $N$-(carboxymethylidene)chitosans and $N$-(carboxymethyl)chitosans: Novel chelating polyampholytes obtained from chitosan glyoxylate. Carbohydrate Research, 107, 199-214.

Muzzarelli, R. A. A., Weckx, M., Filippini, O., \& Lough, C. (1989) Characteristic properties of $\mathrm{N}$-(carboxybutyl)chitosan. Carbohydrate Polymers, 11, 307-320.

Parra-Barraza, H., Burboa, M. G., Sánchez-Vázquez, M., Juárez, J., Goycoolea, F. M., \& Valdez, M. A. (2005). Chitosan-cholesterol and chitosan-stearic acid interactions at the air-water interface. Biomacromolecules, 6, 2416-2426.

Santos, J. E., Dockal, E. R., \& Cavalheiro, E. T. G. (2005). Synthesis and characterization of Schiff bases from chitosan and salicylaldehyde derivatives. Carbohydrate Polymers, 60, 277-282. 
Skorik, Y. A., Gomes, C. A. R., Podberezskaya, N. V., Romanenko, G. V., Pinto, L. F., \& Yatluk, Y. G. (2005). Complexation models of $N$-(2-carboxyethyl)chitosans with copper (II) ions. Biomacromolecules, 6, 189-195.

Skorik, Y. A., Gomes, C. A. R., Vasconcelos, T. S. D., \& Yatluk, Y. G. (2003). $N$-(2-carboxyethyl)chitosan: Regioselective synthesis, characterization and protolytic equilibria. Carbohydrate Research, 338, 271-276.
Smart, J. D., Kellaway, I. W., \& Worthington, H. E. C. (1984). An in vitro investigation of mucosa-adhesive materials for use in controlled drug delivery. Journal of Pharmacy and Pharmacology, 36, 295-299.

Varna, A. J., Deshpande, S. V., \& Kennedy, J. K. (2004). Metal complexation by chitosan and its derivates: A review. Carbohydrate Polymers, 55, 77-93. 